\title{
Analysis of measures to enhance energy efficiency and sustainable development of the gas transmission system of Ukraine
}

\author{
Ihor V. Rybitskyi \\ Ivano-Frankivsk National Technical University \\ of Oil and Gas, Ukraine \\ Mykyta B. Slobodyan \\ Public Joint Stock Company "UKRTRANSGAZ", Kyiv, Ukraine \\ Galyna M. Kogut, Vasyl Ya Popovych, Maksym O. Karpash \\ Ivano-Frankivsk National Technical University \\ of Oil and Gas, Ukraine
}

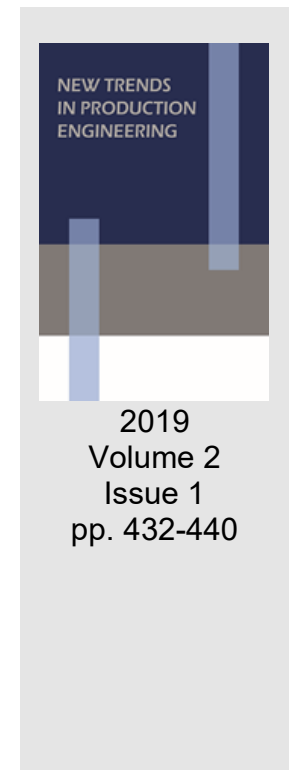

Date of submission to the Editor: 05/2019

Date of acceptance by the Editor: 08/2019

\section{INTRODUCTION}

In the modern world, a stable functioning energy sector and reliable sources of energy supply are the key to the success and sustainable development of any country. The degree of energy and electricity supply is one of the main factors determining the level of economic and technical development of each country. That is why the change of energy consumption strategies (Omer, 2008; Stern, 2017) is a complex task that requires flexible cooperation (World energy Council, 2019) to develop and implement innovative solutions (Wehnert et al., 2018) aimed at achieving the goals of sustainable development (Pradhan et al., 2017; Grubleret al., 2018; Grerghinaet al., 2018).

The fuel and energy complex is an integral part of economic and social wellbeing. That is why this topic is relevant for Ukraine, especially at the present stage of development, when the problem of energy supply and energy efficiency has become extremely acute. According to The World Energy Council's Energy Trilemma Index (World energy Council, 2019), in 2018 Ukraine is ranked 57 out of 125 countries (in 2016 - 63, in 2017 - 48). Despite the increased Energy Security index from 28 in 2016 to 8 in 2018, Ukraine is still remaining downstream position in Environmental Sustainability: in 2016 - 108, in 2017 102 , in 2018 - 113. That's why the energy companies' activities have to be directed to creating and maintaining secure, equitable and sustainable energy supply by decreasing costs and fuel and energy resources' losses (Chu and Majumdar, 2012; Bauer et al., 2016)at all stages of the life cycle from design to utilization (US Department of Justice, 2003). 


\section{DISCUSSION AND RESULTS}

In gas transmission companies of Ukraine, Public Joint Stock Company (PJSC) "UKRTRANSGAZ" in particular, as well as in the branch company DMGP "PRYKARPATRANSGAZ", activities in the part of planning and implementation of energy saving measures (EM) are conducted in accordance with the relevant regulatory documents (SOU 60.3-30019801-019:2005, SOU 60.3-30019801096:2012).

The purpose of this work is to conduct the analysis of organizational, procedural and technical measures implemented at PJSC "UKRTRANSGAZ" and its subdivisions in order to increase energy efficiency at the objects of the Ukrainian gas transmission system.

The above mentioned normative documents provide for the following sequence of actions: according to (SOU 60.3-30019801-096:2012), the structural subdivisions of the branch companies provide proposals for measures to save fuel and energy resources (FER) for the next year; the savings measures are considered at the branch level and their wording is being implemented in the Program of measures for saving and preventing over-expenditures. Organizational and technical measures are planned at three levels (SOU 60.330019801-019:2005):

1. liner production departments of main gas pipelines of branch companies (LPDMGP), production department of gas underground storage;

2. Department of main gas pipelines (DMGP), "Ukravtogaz" and other branch companies of PJSC "UKRTRANSGAZ" (if necessary).

3. PJSC "UKRTRANSGAZ".

PJSC "UKRTRANSGAZ" develops List of organizational and technical measures for saving FER in PJSC" UKRTRANSGAZ (hereinafter referred to as the "List"), which, after approval by the management of PJSC "UKRTRANSGAZ", is communicated to all production branches of PJSC "UKRTRANSGAZ". The list is the basis for the development of the "Program for saving and preventing the over-expenditures of FERs" (hereinafter referred to as the "Program") for the planned period.

The Program for the planned period is being developed, based on the task of a higher level company and taking into account it's financial capacity. The approved Program is communicated to all branches and subdivisions. The List and the Program are adjusted once a year on the basis of proposals of PJSC "UKRTRANSGAZ" branch companies.

A prerequisite for inclusion in the List of additional (new) measures are: their concreteness and controllability; the accuracy of calculating the values of saving or preventing overspending of gas per unit of power equipment; availability of full technical documentation; economic expediency.

The measure, proposed for inclusion in the List and included in the Program, is issued in the form of an explanatory note, which includes: a description of the technical event; the document on the basis of which the measure is proposed; the object where the event will be implemented; initial data for calculation; calculation algorithm; calculation of the cost of implementing the event; 
calculation of the economic effect of the implementation of the event, taking into account all costs. Properly executed, the explanatory note is signed by the performer or person responsible for its preparation and approved by the management of the enterprise (Prodan et al., 2008).

Measures to save fuel and energy resources are grouped according to the following criteria (SOU 60.3-30019801-096:2012): measures to save and prevent over-expenditures of natural gas at compressor stations (CS) measures to save natural gas on the linear part of main gas pipelines (LPMP) measures to save and prevent overspending of natural gas in heating systems; measures to save and prevent the overuse of electricity at the compressor station of the CS, LPMP and boilers; measures to save and prevent over-expenditures of motor fuel, fuel and lubricants used in road transport; measures to save and prevent waste of lubricants.

So in the standard (SOU 60.3-30019801-096:2012) potential energy resources that can be saved are: natural gas; electricity; heat energy; fuels and lubricants. However, in the standard (SOU 60.3-30019801-096:2012) the attentions are not payed at all to the possibility of saving the water used.

In general, energy-saving measures are divided into those that lead to energy savings and measures that lead to the prevention of their cost overruns. For example, measures, the results of which significantly increase the efficiency of power equipment, provide real savings of natural gas or electricity, and measures, the implementation of which allows to restore the technical and economic characteristics of power equipment to the level of declared or normalized values (usually during all types of capital and emergency repairs) all these are the measures to prevent gas or electricity overspending and their real savings are not achieved.

Measures that provide savings from their implementation are divided into technical (reconstruction, modernization of equipment or technological process, etc.) and optimization (for example, ensuring the operation of the injector in the zone of maximum possible values of polytropic performance factor). There are different activities, the implementation of which ensures the saving of fuel and energy resources at a technological facility, using energy, and the measures, the implementation of which at this facility provides energy savings at other facilities (Khaliavka, 2004).

Formulated methods for calculating savings from the implementation of energysaving measures for specific equipment include the determination of the necessary indicators, such as performance factor, fuel consumption, power consumption, etc., according to the results of field tests and parameter measurements.

The value of fuel and energy saving for each process is calculated per unit of energy-consuming facility or a technological operation. Expected savings and avoidance of energy waste from the implementation of a technical measure are calculated for the entire planned period in accordance with the term for evaluating the operation of the equipment. The value of expected savings and unacceptable overspending of fuel and energy resources on implementation of 
a technical measure for the planned year is calculated taking into account the average operating time of the equipment for the previous three years.

The value of savings and avoidance of overspending of fuel and energy resources for the year from the implemented measure is generally calculated using the formula (SOU 60.3-30019801-019:2005):

$$
Q_{E_{i}}=\Delta q \cdot \frac{\tau_{p}}{8760}
$$

where:

$\Delta q-$ is the corresponding specific value of saving or preventing overruns of fuel and energy resources for the year from the implementation of the event per unit of power equipment (provided that 8760 hours of operation), thousand tons of reference fuel, kW; Gcal.,

$\tau_{p}$ - average value of equipment operating time for the previous three years, $\mathrm{h}$.

For planning, the amount of savings and the avoidance of overruns of fuel and energy resources for a long-term period from an event that is implemented gradually over a certain amount of equipment is calculated by the formula (SOU 60.3-30019801-019:2005):

$$
Q_{E_{i}}=\Delta q \cdot \sum_{i=1}^{k}\left(n_{i}\right) \frac{\tau_{p}}{8760}
$$

where:

$n_{i}$ - number of power equipment, to implement the measure, in $i$-th year;

$k$ - number of years for which the saving are intended to be obtained.

The number of equipment operating in the $i$-th year is calculated by the formula:

$$
n_{i}=m_{1}+m_{2} \ldots+\frac{m_{i}}{2}
$$

where:

$m_{1}$ - number of equipment on which the energy saving measures will be implemented in the first year planned,

$m_{2}-$ number of equipment on which the energy saving measures will be implemented in the second year planned;

$m_{i}$ - number of equipment on which the energy saving measures will be implemented in the last year planned.

Basically, in the branch company DMGP "Prykarpattransgaz" savings are achieved as a result of the use of organizational and technical measures (costfree), as well as measures with minor financial investments such as: cleaning the flow part of axial compressors; optimization of the anti-icer system; modern technologies implementation for repairing gas pipelines under pressure (couplings, bandages, cavern welding, etc.); gas offtake by consumers to the lowest possible pressure from the gas pipeline section before performing repairs on it; the use of recycled exhaust heat; decommissioning of unloaded power transformers, replacement with less powerful ones; rational loading of gas cooling fans; gas pass on communications and process equipment before performing repair work; gas transmission from sections of gas pipelines requiring repair, or metering sections during scheduled replacement of 
diaphragms into gas pipelines with lower pressure; utilization of gas in utilities and process equipment and gas drying facilities installation.

For the subsequent analysis of the implementation of energy-saving measures aimed at saving and preventing over-expenditure of fuel and energy resources in the branch company DMGP " Prykarpattransgaz " during 2010-2016, we will provide information both on the planned indicators (Table 1) for this period and on the actual savings.

Table 1 Plan for saving and avoidance of over-expenditures of FER at DMGP " Prykarpattransgaz " in 2010-2016

\begin{tabular}{|c|l|c|c|c|c|c|c|c|c|}
\hline No. & \multicolumn{1}{|c|}{ Indicators } & $\mathbf{2 0 1 0}$ & $\mathbf{2 0 1 1}$ & $\mathbf{2 0 1 2}$ & $\mathbf{2 0 1 3}$ & $\mathbf{2 0 1 4}$ & $\mathbf{2 0 1 5}$ & $\mathbf{2 0 1 6}$ & Total \\
\hline 1 & $\begin{array}{l}\text { Plan for natural gas saving, } \\
\text { million cubic meters }\end{array}$ & 16.6 & 17.2 & 41.3 & 29.0 & 22.2 & 29.7 & 17.2 & $\mathbf{1 7 3 . 2}$ \\
\hline 2 & $\begin{array}{l}\text { Plan for electricity saving, } \\
\text { million kVh }\end{array}$ & 1.0 & 0.7 & 0.6 & 1.3 & 0.8 & 1.5 & 1.5 & $\mathbf{7 . 4}$ \\
\hline 3 & $\begin{array}{l}\text { Plan for financing the } \\
\text { natural gas saving } \\
\text { measures, million UAH }\end{array}$ & 21.3 & 27.1 & 59.1 & 20.6 & 2.5 & 4.5 & 23.0 & $\mathbf{1 5 8 . 1}$ \\
\hline 4 & $\begin{array}{l}\text { Plan for financing the } \\
\text { electricity saving measures, } \\
\text { million UAH }\end{array}$ & 5.2 & 5.1 & 1.2 & 1.6 & 3.6 & 2.4 & 3.3 & $\mathbf{2 2 . 4}$ \\
\hline
\end{tabular}

(Table 2), as well as funds that were planned for the implementation of energy saving measures and actual financial investments were directed to them.

Table 2 Actual saving and avoidance of over-expenditures of FER at DMGP "Prykarpattransgaz" in 2010-2016

\begin{tabular}{|c|l|c|c|c|c|c|c|c|c|}
\hline No. & \multicolumn{1}{|c|}{ Indicators } & $\mathbf{2 0 1 0}$ & $\mathbf{2 0 1 1}$ & $\mathbf{2 0 1 2}$ & $\mathbf{2 0 1 3}$ & $\mathbf{2 0 1 4}$ & $\mathbf{2 0 1 5}$ & $\mathbf{2 0 1 6}$ & Total \\
\hline 1 & $\begin{array}{l}\text { Actual natural gas saving, } \\
\text { million cubic meters }\end{array}$ & $\mathbf{4 4 . 0}$ & 46.0 & 32.5 & 29.8 & 22.7 & 38.7 & 81.1 & $\mathbf{2 9 4 . 8}$ \\
\hline 2 & $\begin{array}{l}\text { Actual electricity saving, } \\
\text { million kV h }\end{array}$ & 0.6 & 1.2 & 1.1 & 0.8 & 1.2 & 0.8 & 2.0 & $\mathbf{7 . 7}$ \\
\hline 3 & $\begin{array}{l}\text { Costs for implementation of } \\
\text { natural gas saving } \\
\text { measures, mil. UAH }\end{array}$ & 2.3 & 35.0 & 26.4 & 36.0 & 4.6 & 0.8 & 4.9 & $\mathbf{1 1 0 . 0}$ \\
\hline 4 & $\begin{array}{l}\text { Costs for implementation of } \\
\text { electricity saving measures, } \\
\text { mil. UAH }\end{array}$ & 0.0 & 0.2 & 0.0 & 0.0 & 0.0 & 0.0 & 1.6 & $\mathbf{1 . 8}$ \\
\hline
\end{tabular}

As follows from the tables above, the planned and actual savings in the implementation of classical measures in the branch company DMGP "Prykarpattransgaz" have very great differences, primarily due to poor systematization and coordination of the energy efficiency process.

In times of great change, crisis, financial and economic instability, every large energy-intensive enterprise must feasibly and efficiently use its energy reserves (FER) for its effective functioning. Only such an approach in the present unstable situation can provide competitiveness and a certain "margin of safety" to the enterprise.

DMGP "Prykarpattransgaz" has always paid attention to issues that are directly related to the sphere of energy saving and the introduction of new technologies. In recent years, energy saving has become an almost integral part in the 
production process of transporting natural gas through a gas transmission system.

The gradual steps taken by DMGP "Prykarpattransgaz" towards energy saving gave certain positive results. In particular:

- reduction of gas consumption for production and technological needs;

- reduction of natural gas losses in the production process of gas transportation;

- saving significant volumes of fuel and energy resources (gas, electricity, etc.).

The implementation of energy-saving measures aimed at reducing gas consumption for production and technological needs allows to reduce methane emissions to the environment, which has a positive effect on our ecosystem and does not lead to the taking actions of influence from supervisory environmental inspections.

For the most effective implementation of the energy saving system, it is necessary to use a single set of measures aimed at improving the energy efficiency of gas transmission system facilities in Ukraine, as well as its systematic implementation at all operation levels of the gas transportation process, which in turn will improve the energy efficiency of the GTS facilities, and will also contribute to the achievement of such goals as environmental saving (reduction of greenhouse gas emissions, etc.); conservation of energy resources; renewable energy resources use.

Among the priorities for implementation at Ukraine's GTS facilities, besides the replacement of inefficient, outdated gas pumping units with low efficiency, there are such measures as the installation of cogeneration plants, turbo-expanded power plants, infrared emitters, wind power plants; reconstruction of lighting systems; modernization of boiler equipment and heating networks.

Highly promising in the gas industry is the installation of cogeneration plants, producing electricity, which will be used to drive the gas pumping units, instead of natural gas. At compressor stations it is necessary to mount cogeneration plants on industrial sites directly at the gas pumping units. Taking into account technological issues of installation, it is necessary to use the waste heat of the exhaust gases from operating gas turbine engines, which will reduce the consumption of natural gas as fuel for driving gas pumping unit, thereby reducing the energy intensity of the gas transmission industry.

For utilization of excess gas pressure energy in the transmission systems from compressor stations to consumers, instead of control valves the turbo-expander power generating installations and units are used, which simultaneously reduce the gas pressure and convert the resulting mechanical energy into electricity. A significant share in the structure of natural gas consumption is occupied by equipment, intended for space heating, and the most common type of which are boiler installations. To regulate heating in large premises, it is necessary to choose the right place for the installation of the heating system's batteries, to create additional conditions for the movement of warm air in the specific direction to the specific areas. The use of infrared radiation to transfer heat from 
a source to a local (specific) object in this case has several advantages. The main purpose of such method of heating is local heating of objects, which may be: workers, workplaces, appliances, and machines. The infrared gas heater is able to operate on both low-pressure natural gas and liquefied gas (in cylinders). One of the main trends in the development of renewable energy sources today is wind power, namely the installation and operation of wind power plants. The use of electricity produced by wind turbines is able to supply the following facilities at a compressor station: production premises (shops, storage structures, hangars), boiler rooms, etc.; automatic fire extinguishing systems, emergency units, etc.; household premises of the station (canteens, bathrooms, buffets, gatehouses). To meet the needs of the facility (CS) with electricity in the amount of 2-2.5 million $\mathrm{kWh}$ per year, it is sufficient to install $800 \mathrm{~kW}$ wind turbine.

The gas transportation industry of Ukraine needs a significant amount of highquality light energy to organize a normal production process. The industry includes a large number of production facilities that require a lot of lighting fixtures. Therefore, when choosing lighting fixtures, one should be guided by three main requirements: compliance with regulatory requirements; use of lighting devices in explosion-proof performance; use of lighting devices with minimal power consumption.

Recognizing the importance of energy-saving measures and technologies implementation in the production of Ukraine, it is necessary to create a strong legislative and regulatory framework that became the foundation for ensuring the growth of their implementation.

After all, all these measures will allow to achieve necessary result in the transition to a climate-neutral economy based on renewable sources, that nowadays comes with significant challenges in terms of transportation of natural gas. Despite the fact, that Ukrainian gas infrastructure is extensive and its capabilities are valuable for enabling a cross-sectorial emission reduction with the potential to climate-neutral industry, this requires a rapid changeover from the use of emission intensive sources and technologies to climate-friendly and their intensive use.

\section{CONCLUSIONS}

1. Based on the analysis of existing regulatory documents in the field of energy saving, organizational and technical measures were described in detail, aimed at ensuring the rational use of fuel and energy resources at PJSC "UKRTRANSGAZ".

2. The measures that make for energy savings and avoidance of their cost overruns were analyzed, their differences and implementation procedures at existing facilities were shown, the dependencies of the calculation of saving fuel and energy resources at these facilities were presented.

3. The given analysis of planned and actual savings indicators showed a significant discrepancy in the implementation of classical energy saving 
measures through the coordination and systematization of energy efficient processes.

4. The promising areas of the renewable energy sources implementation to improve energy efficiency at gas transmission facilities were analyzed.

5. In case of sustainable development it is necessary to set the science-based climate targets for reducing green-house gas emissions that finally would foster low-carbon production technologies and industrial energy-efficiency.

\section{REFERENCES}

Omer, A. M. (2008). Energy, environment and sustainable development. Renewable and Sustainable Energy Reviews, 12(9), 2265-2300. doi:10.1016/j.rser.2007.05.001.

Stern, J. (2017). The Future of Gas in Decarbonizing European Energy Markets - the need for a new approach. [online] Oxford Institute for Energy Studies. Available at: $\quad$ https://www.oxfordenergy.org/wpcms/wp-content/uploads/2017/01/TheFuture-of-Gas-in-Decarbonising-European-Energy-Markets-the-need-for-a-newapproach-NG-116.pdf [Accessed June 18, 2019].

World Energy Insights Brief - Global Energy Scenarios Comparison Review.[online] World Energy Council. Available at: https://www.worldenergy.org/wpcontent/uploads/2019/04/WEInsights-Brief-Global-Energy-ScenariosComparison-Review-R02.pdf [Accessed June 24, 2019].

Wehnert, P.; Kollwitz, C.; Daiberl, C.; Dinter, B.; Beckmann, M. Capturing the Bigger Picture? Applying Text Analytics to Foster Open Innovation Processes for Sustainability-Oriented Innovation. [online] Sustainability 2018, 10, 3710. Available at: https://www.mdpi.com/2071-1050/10/10/3710 [Accessed June 03, 2019].

Pradhan, P., Costa, L., Rybski, D., Lucht, W., \& Kropp, J. P. (2017). A Systematic Study of Sustainable Development Goal (SDG) Interactions. Earth's Future, 5(11), 1169-1179.doi:10.1002/2017ef000632.

Grubler, A., Wilson, C., Bento, N., Boza-Kiss, B., Krey, V., McCollum, D. L., Valin, H. (2018). A low energy demand scenario for meeting the $1.5^{\circ} \mathrm{C}$ target and sustainable development goals without negative emission technologies. Nature Energy, 3(6), 515-527.doi:10.1038/s41560-018-0172-6.

Pradhan, P., Costa, L., Rybski, D., Lucht, W., \& Kropp, J. P. (2017). A Systematic Study of Sustainable Development Goal (SDG) Interactions. Earth's Future, 5(11), 1169-1179.doi:10.1002/2017ef000632.

Gherghina, Ş.C.; Onofrei, M.; Vintilă, G.; Armeanu, D.Ş. Empirical Evidence from EU28 Countries on Resilient Transport Infrastructure Systems and Sustainable Economic Growth. [online] Sustainability 2018, 10, 2900 Available at: https://www.worldenergy. org/wp-content/uploads/2019/04/WEInsights-BriefGlobal-Energy-Scenarios-Comparison-Review-R02.pdf [Accessed June 24, 2019].

World Energy Trilemma Index 2018 (2019)[online] / World Energy Council. Available at: $\quad$ https://www.worldenergy.org/wp-content/uploads/2018/10/World-EnergyTrilemma-Index-2018.pdf [Accessed June 18, 2019].

Chu, S., \& Majumdar, A. (2012). Opportunities and challenges for a sustainable energy future. Nature, 488(7411), 294-303. doi:10.1038/nature11475.

Bauer, N., Mouratiadou, I., Luderer, G. et al. Climatic Change (2016) 136: 69. https://doi.org/10.1007/s10584-013-0901-6.

US Department of Justice (2003). Information Resources Management. Chapter 1. Introduction. [online] Available at: https://www.justice.gov/archive/jmd/irm/ lifecycle/ch1. htm [Accessed April 24, 2019]. 
SOU 60.3-30019801-019:2005 Enerho zberezhennia. Planuvannia ta oblikvy konannia orhanizatsiino-tekhnichnyk hzakhodivshchodo ekonomii palyvno-enerhetychnyk hresursiv (2005) Kyiv: DK «Ukrtranshaz», 2005 [In Ukrainian].

SOU 60.3-30019801-096:2012 Ekonomiia palyvno-enerhetychny khresursiv vid vprovadzhennia enerho zberihaiuchy khzakhodiv v DK «Ukrtranshaz». Metody vyznachennia (2012), Kyiv: DK «Ukrtranshaz», 2012 [In Ukrainian].

Enerhetychna bezpeka Ukrainy: otsinka ta napriamky zabezpechennia / za red. Yu. V. Prodana, B. S. Stohniia; NAN Ukrainy, Nats. tekhn. un-t Ukrainy "Kyiv. politekhn. instytut". - Kyiv, 2008. - $400 \mathrm{p}$ [In Ukrainian].

Khaliavka N.P. Resurs o enerho zberezhennia / Pid red. akad. UNHA, k.t.n. Khaliavka N.P., k.t.n. Khaliavka K.P., k.t.n. Prozorova M.V. - K.: PVP «Zadruha», 2004 [In Ukrainian].

\begin{abstract}
.
The requirements of the fundamental normative documents in Public Joint Stock Company "UKRTRANSGAS", regulating activities in the sphere of energy efficiency, are considered and analyzed. The procedure for implementation of energy saving measures and controlling over their implementation is presented. The analysis of planned and actual indicators of fuel and energy resources saving has been carried out. The ways to improve energy efficiency with the use of renewable energy sources are given.
\end{abstract}

Keywords: energy efficiency, gas transmission system, fuel and energy resources, energy saving, sustainable development 